\title{
Sloane, Barney.
}

The Augustinian Nunnery of St. Mary Clerkenwell, London: Excavations 1974-96.

MOLA Monograph 57. London: Museum of London Archaeology, 2012. Pp. xvii, $278+149$ ill, 47 tables, 1 CD with 50 tables. ISBN 978-1-901992-04-5 (hardcover) $£ 24$.

Compared with male religious houses, medieval nunneries in Britain received little attention until the late 1980s when Roberta Gilchrist began publishing her ground-breaking work on the archaeology of medieval English nunneries. In his comprehensive study of the Augustinian Nunnery of St. Mary Clerkenwell, Barney Sloane pays tribute to Gilchrist's innovative approach in which she demonstrated how issues of "function, gender and symbolism" had an impact on "the process of foundation, choice of site, evolution of plan form and symbolism of material culture." His report, as he observes, has benefitted from the research framework Gilchrist provided (1-2). Beyond this, he notes that St. Mary Clerkenwell can be seen as part of three other constituencies: first, as one of just 22 houses of Augustinian canonesses in England and Wales; second, as a member of a range of nunneries in and around London; and third, as belonging to "a religious 'enclave" immediately to the northwest of the city defences. This last includes three houses, the first two of which have been the subject of volumes in this series-St. John Clerkenwell, the premier house of the Hospitallers in England, and the London Charterhouse-and the third being the twelfthcentury priory and hospital of St. Bartholomew Smithfield, City of London. Finally, in investigating St. Mary Clerkenwell as one of six medieval nunneries in the London area, a grouping unique to England, Sloane sees considerable potential to study the material culture of religious women in relation to the largest city in the kingdom.

Throughout, the report has been meticulously documented, and researchers seeking further detail can, by means of numerical designations and computerized indices, refer back to the specialist research archives produced by Museum of London Archaeology, or MOLA. The material has been organized into three clearly demarcated components: first, the chronological narrative, based on dated periods, comprises three chapters, pre-medieval (2), medieval (3), and the Dissolution and after (5), each one beginning with documentary evidence followed by archaeological activity and its results, and concluding with 
a discussion and summary; second, thematic chapters (4,5, and 6) allow for the discussion of the changing nature of the nunnery and its inhabitants over time; and third, specialist and technical support appendices, supplemented by $C D$ tables, conclude the investigation.

While primarily a "scientific" report, this volume has a great deal to offer those interested in English religious houses for women. The priory of St. Mary Clerkenwell was founded around 1144 by a lay knight, Jordan de Bricet, and his wife, Muriel de Munteni, who had recently founded the neighbouring priory of the Order of the Hospital of St. John of Jerusalem. Robert the chaplain, who had assisted with the earlier foundation, was given charge of the de Bricet endowments for "a house of prayer ... for grey monks [probably of the Savigniac Order] or nuns." Robert chose nuns, perhaps, as Sloane suggests, because as a chaplain he would have had a vested interest. The land for both foundations came from Jordan's fee of Clerkenwell, identified as five hides in Stepney held in 1086 by his grandmother from the bishop of London (17). Although one might expect that Jordan would favour his male foundation, when he died (ca. 1160), he was, in fact, buried in the chapter house of St. Mary. Family connections may have been the deciding factor.

Incidental information also throws light more generally on religious communities of women. Among some key examples is the Clerks' well, or fons clericorum (since 1982 uncovered and on display to the public), well known before the foundation of the nunnery and likely a factor in determining the location of St. Mary's. As Sloane notes, a number of London nunneries were associated with wells, and one could add that this is not unusual elsewhere too, as often the waters were thought to have curative powers. The need for priests to serve and assist women religious gave rise to various solutions. In 1131 Gilbert of Sempringham founded his order of nuns, but a decade or so later he added Augustinian canons to serve his monasteries. For her community of nuns, St. Bridget of Sweden (ca. 1303-73) included priest-brothers and deacons as part of the enclosed order. At Clerkenwell a similar need seems to have been addressed by the presence of chaplains and brethren, as shown by the fact that they were witnesses to charters, and within the precincts there seems to have been a building where they may have lived communally. In the 1190s, Sloane speculates that there may have been seventeen nuns and at least eight chaplains and seven brethren (28). The church itself, dated to ca. 1150 and later expanded (each expansion methodically documented), also served as a parish 
church and seems to have had a "high quire" for the nuns and a "parish altar"; the nuns' altar was dedicated to St. Mary, and evidence suggests that the parish altar was rededicated to St. James before the Dissolution, perhaps in the mid- to late-fourteenth century (77) and certainly by the late-fifteenth century (96). In September 1539 the house was surrendered and the prioress and eleven nuns expelled and granted pensions. The north aisle of the church, or part associated with the nuns, was removed (182) and the lead from part of the cloister roof stripped in 1541 for the repair of Westminster Hall (183). The parish church of St. James, however, remained until 1788-89, when it was demolished. Fine illustrations have allowed for its virtual reconstruction, and these can be viewed as part of the volume's generous illustrative material.

While it is not possible to mention all the data provided in the report, the accounts of the lands and tithes, the patrons, the church, the precincts, the inner and outer courts, the tenements, the tenants, the appointment of stewards to help collect rents, and more, do much to convey a sense of the varied community of which the nunnery was but one part. Such variety, as we know from well-studied houses such as the Bridgettine Syon Abbey, established by Henry V in 1415, was not uncommon in women's religious communities. Even if Sloane's study does not set out to chronicle the spiritual life of the nuns and their daily routine, it does offer information on almost anything else one may wish to know about St. Mary Clerkenwell.

ANN M. HUTCHISON

Glendon College, York University 